\title{
Adaptability of Naked Barley Landraces in Mountain Agro-ecosystem of Nepal
}

Krishna Hari Ghimire ${ }^{1 @}$, Bal Krishna Joshi ${ }^{1}$, Rita Gurung ${ }^{2}$, Epsha Palikhey ${ }^{2}$, Niranjan Pudasaini ${ }^{2}$ and Aruna Parajuli $^{2}$

${ }^{1}$ National Agriculture Genetic Resources Centre, NARC, Khumaltar, Nepal. @: ghimirekh@gmail.com, ORCID: http://orcid.org/0000-0002-3393-290X; BKJ: joshibalak@yahoo.com

${ }^{2}$ Local Initiatives for Biodiversity, Research and Development (LIBIRD), Pokhara, Nepal; RG: rgurung@libird.org; NP: niranjan.pudasaini@libird.org

Received 19 Dec 2018, Revised 4 Jan 2019, Accepted 7 Feb 2019, Published 28 April 2019

Scientific Editors: Jiban Shrestha, Tek B. Gurung, Umesh K. Acharya

Copyright (C) 2019 NARC. Permits unrestricted use, distribution and reproduction in any medium provided the original work is properly cited.

The authors declare that there is no conflict of interest.

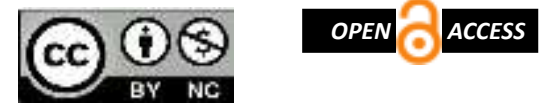

Licensed under the Creative Commons AttributionNonCommercial 4.0 International (CC BY-NC 4.0)

\begin{abstract}
Naked barley (Hordeum vulgare var. nudum L.) is an important food crop in mountain regions of Nepal, however, its production area and genetic diversity is known to be shrinking fast. One of the reasons could be the poor productivity. To improve the productivity of crops, it is essential that new site-specific, high-yielding and widely adopted varietal options for farmers should be developed for sustainability. To identify the varietal responses to environment, multi-location testing is one of the main tools. Following this, we evaluated agronomic performance of eight naked barley landraces collected from five different locations of Nepal with altitude ranging from 1370 to 2500 meter elevations from the sea level during the winter season of 2014/15 in order to assess the landraces adaptability across different locations. Combined analysis of variances revealed that NGRC02306, NGRC04902 and NGRC04894 were the high yielding landraces. The landrace namely NGRC04894 was found the most stable genotype with better adaptability to all tested environments whereas NGRC02306 and NGRC04902 were high yielding landraces adapted to high yielding environment namely Khumaltar. However, the lower yielding landrace NGRC02327 was the earliest and could be preferred by farmers as its maturity allows it to fit better in the rice based cropping system. Our study showed that these landraces need to be verified further in farmers' fields and the release of one or more of them would help to diversify the genetic base of naked barley varieties in the seed supply system.
\end{abstract}

Keywords: Adaptability, GxE interaction, landrace, naked barley, stable genotype

\section{सारांश}

उवा नेपालको हिमाली भेगको एक महत्वपूर्ण खाद्यान्न बाली हो तर यसको उत्पादन क्षेत्रफल र आनुवंशिक विविधता दुततर गतिमा घट्दो छ, जसको प्रमुख कारण न्यून उत्पादकत्व नै हो । उत्पादकत्वमा सुधारको निम्ति धेरै फल्ने, छिटो पाक्ने, स्थान विशेष र धेरै ठाउँहरुमा खेती गर्न सकिने जातहरु छनोट गरी कृषकहरुलाई वैकल्पिक जातहरु उपलब्ध गराउनु अत्यन्त जरुरी हुन्छ। विविध जातहरुको विभिन्न हावापानीमा हुने अन्तरक्या थाह पाउन बहुस्थलीय परिक्षणहरु उपयुक्त माध्यम हुन्छन् । आठवटा जातहरु समावेश गरी वि.सं. २०७१ सालको हिउँदमा उच्च पहाडी तथा हिमाली भेगका समुन्द्र सतहबाट १३७० देखि २प०० मिटरसम्म उचाइका पाँच स्थानहरुमा उवाको जातीय परिक्षणहरु संचालन गरिएको थियो । परिक्षणको नतिजाले NGRC02306, NGRC04902 र NGRC04894 ले धेरै उत्पादन दिएको देखायो । तर उत्पादन कम भए तापनि अरुभन्दा छिटो पाक्ने र धान बालीमा आधारित बाली प्रणालीमा सुहाउँदो भएकोले NGRC02327 लाई कृषकहरुले धेरै मन पराउन सक्ने देखिन्छ । परिक्षण गरिएका जातहरु र वातावरण (स्थानहरु) बीचमा उच्च अन्तरक्रिया देखिएकोले स्थान बिशेषको लागि छुट्छाछुट्टै जातहरु छनोट गर्नुपर्ने देखिन्छ । स्थानको औसत र जातको औसतलाई विश्लेषण गर्दा NGRC04894 सबै स्थानमा राम्रो गरेकोले सबैभन्दा स्थिर जात देखिएको छ भने NGRC02306 र NGRC04902 चाहिं खुमलटार जस्तो राम्रो र धेरै उत्पादन दिने वातावरणमा धेरै फल्ने देखिन्छ । यी जातहरुलाई अकै व्यापक रुपमा कषकको खेतबारीमा परिक्षण गरी सिफारिस गर्न सकेमा उवाको बीउ वितरण प्रणालीमा सुधार आउने र हिमाली भेगको खाद्य सुरक्षामा टेवा पुग्ने देखिन्छ । 


\section{INTRODUCTION}

Barley (Hordeum vulgare L.) is a winter self-pollinated cereal grain known to be cultivated since ancient time. The barley is known to be originated in the Himalayan region, particularly in Bhutan, Nepal and Tibet of China (Singh 1983, Rajbhandari and Bhatta 2008). It is the second most important winter crop in mountainous regions of Nepal. It is grown in different cropping patterns in both Khet (irrigated lowlands) and Bari (non-irrigated uplands) conditions. Barley landraces dominate cultivation and grows in the low fertility rainfed environment of the high-hills of Nepal. It is the second most preferred crop after rice in Jumla (Baniya et al 1997). Studies revealed diversity in Nepalese barley landraces in accordance the theory that Nepal is a primary center of diversity (Witcombe 1975, Witcombe and Gilani 1979, Murphy and Witcombe 1986, Bajracharya et al 2012).

Two types of barley are being cultivated in Nepal: hulled or covered and hullless or naked. Naked barley differs from covered barley by the loose husk cover of caryopsis that is easily separable upon threshing in contrast to hulled barley (Bhatty 1999). Although naked barley is less yielding than the hulled type, it received more attention recently as healthy human food due to the abundance of dietary factors mainly $\beta$-glucans (which is an inhibitor of cholesterol synthesis), and vitamins (Manjunatha et al 2011, Tonoka et al 2009). Naked and covered barley differ greatly in their spike morphology (Murphy and Witcombe 1986).

Naked barley (Hordeum vulgare var. nudum L.) is an important food crop in mountain region of Nepal but production area and genetic diversity is shrinking fast. Only one variety viz Solu uwa is released which was selected from landrace of the Solukhumbu district. In order to increase varietal options, field trials were designed to identify high-yielding, early-maturing and site-specific as well as widely adopted landraces of naked barley for the mountain region.

In Nepal, barley is grown in 28053 ha area with the average productivity of $1.33 \mathrm{t} / \mathrm{ha}$ (MOAD, 2015), however, disaggregated data for naked barley are lacking. As compared to covered barley, naked barley grains contain up to $16 \%$ higher protein content (Saud, 2010). It is utilized as different traditional food items, quality beverages and feed for animals in high mountain areas of Nepal. It is a neglected and under-utilized crop species. No varieties have been released by the Nepal Agricultural Research Council (NARC) after releasing the only variety Solu uwa 27 years ago (Joshi et al 2017, NARC 2012, SQCC 2016) suggesting inadequate research attention for the crop. Despite the several nutritional benefits of naked barley, its cultivation is declining due to changing local food habit, low awareness of the nutritional benefits of naked barley and its low productivity.

In Chhipra village of Humla district, naked barley is the major component to prepare local beer (Chhyang), even though it's area and production is decreasing. Hulled barley is a main crop in Hanku of Jumla Valley and many parts of Jumla district which fits well in rice-barley cropping pattern in well-drained bunded fields (khet land). Naked barley is not commonly grown in Hanku village of Jumla district and nearby areas as it is not a traditionally accepted food and existing landraces of naked barley are low yielding compared with hulled barley at Ghanpokhara and Jugu villages in Lamjung and Dolakha districts, respectively. Therefore, we conducted this research with the objectives of: i) introducing the new crop as well as some landraces diversity collected from other parts of the country to these sites for adaptation, and ii) identifying high yielding and early maturing landraces for different mountain agro-ecosystems.

\section{MATERIAL AND METHODS}

Experimental location

Experiment was conducted at five different locations given in Table 1 and Figure 1. 
Table 1. Geographic and climatic information of experimental locations

\begin{tabular}{lccccc}
\hline Location & \multicolumn{3}{c}{ Geo-reference } & \multicolumn{2}{c}{ Climate } \\
\cline { 2 - 6 } & $\begin{array}{c}\text { Latitude } \\
(\mathbf{N})\end{array}$ & Longitude $(\mathbf{E})$ & $\begin{array}{c}\text { Altitude } \\
(\mathbf{m a s})\end{array}$ & $\begin{array}{c}\text { Average temperature } \\
\text { range }(\mathbf{0 C})\end{array}$ & $\begin{array}{c}\text { Annual rainfall } \\
(\mathbf{m m})\end{array}$ \\
\hline Chhipra, Humla & $29.941^{\circ}$ & $81.853^{\circ}$ & 2200 & $0-20$ & 50 \\
\hline Hanku, Jumla & $29.232^{\circ}$ & $82.095^{\circ}$ & 2500 & $2-22$ & 29 \\
\hline $\begin{array}{l}\text { Ghanpokhara, } \\
\text { Lamjung }\end{array}$ & $28.306^{\circ}$ & $84.324^{\circ}$ & 1550 & $15-27$ & 2944 \\
\hline Jugu, Dolakha & $27.678^{\circ}$ & $86.189^{\circ}$ & 1800 & $4-22$ & $3-29$ \\
\hline Khumaltar, Lalitpur & $27.647^{\circ}$ & $85.324^{\circ}$ & 1370 & & 1382 \\
\hline
\end{tabular}

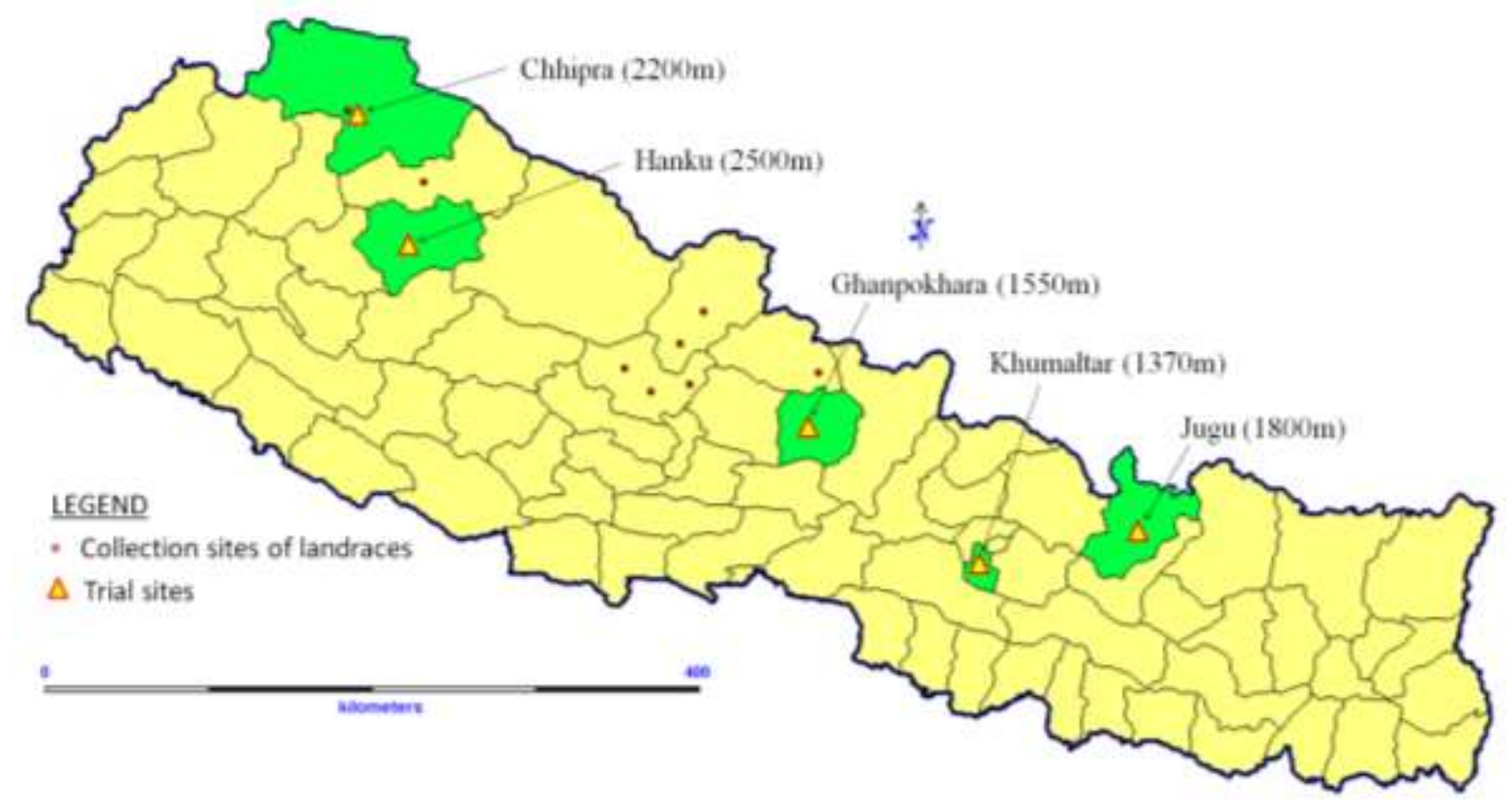

Figure 1. Map of Nepal showing collection sites of test landraces and experiment sites.

Plant materials

Eight landraces of naked barley, collected from different mountain districts of Nepal were used (Table 2).

Table 2. Details of landraces evaluated in 5 different sites during winter of 2014/015

\begin{tabular}{|c|c|c|c|c|c|}
\hline SN & Accession number & Local name & Grain (pericarp) colour & Collected district & Altitude (m) \\
\hline 1 & NGRC04003 & Jau & Black & Mustang & 2800 \\
\hline 2 & NGRC02327 & Uwa & White & Myagdi & 1280 \\
\hline 3 & NGRC04894 & Jau & Purple & Humla & 3500 \\
\hline 4 & NGRC02306 & Uwa & Black & Mustang & 2800 \\
\hline 5 & NGRC04903 & Jhuse uwa & Black & Mugu & 2400 \\
\hline 6 & NGRC04902 & Local uwa & White & Manang & 2050 \\
\hline 7 & NGRC04901 & Uwa & Purple & Myagdi & 1543 \\
\hline 8 & NGRC01137 & Uwa & Black & Myagdi & NA \\
\hline
\end{tabular}

Experimental design and cultural practices

The experiment was conducted in a randomized complete block design (RCBD) with 3 replications. Plot size was 8 rows of $3 \mathrm{~m}$ length $(2 \mathrm{~m} \times 3 \mathrm{~m})$ with spacing of $25 \mathrm{~cm}$ between rows and continuous plants within rows. Fertilizers and other management practices were applied as per the farmers' practice of respective sites. Seeding was done on $27^{\text {th }}$ November, 2014 at Chhipra, $13^{\text {th }}$ Nov, 2014 at Hanku, $6^{\text {th }}$ Nov, 2014 at Ghanpokhara, $14^{\text {th }}$ Nov, 2014 at Jugu and $10^{\text {th }}$ Nov, 2014 at Khumaltar. 


\section{Data observation and statistical analysis}

Agronomic characteristics such as time to heading (days), time to maturity (days), plant height $(\mathrm{cm})$ and grain yield (kg/ha) were recorded following IPGRI descriptors (IPGRI, 1994). Grain yield was recorded after sun drying. Data were analyzed with Microsoft Excel, 2008 and MINITAB V14.1 statistical software. Analysis of variance (ANOVA) was performed using General Linear Model. Regression analysis was used to estimate stability and adaptation of the genotypes (Finley and Wilkinson 1963). The site mean yield was used as the independent variable and the individual genotype yield was used as the dependent variables. Adaptation and stability of genotypes were interpreted based upon the results of regression coefficient $(b)$ and coefficient of determination $\left(R^{2}\right)$ as described by Bilbro and Ray (1976). If regression coefficient is higher than 1, the genotype is adapted to high yielding environment and if the regression is lower than 1, the genotype is adapted to low yielding environments. Genotypes with regression coefficient equal or close to 1 and yield above average were considered more stable and adapted to all environments.

\section{RESULTS}

Phenological characteristics such as days to heading and maturity as well as plant height are important adaptive traits in the harsh environment of the mountain agro-ecosystems. ANOVA was conducted for days to heading and maturity, plant height and grain yield of 8 tested landraces at all 5 sites as well as combined over locations. Highly significant differences were observed among tested landraces for days to heading at all sites except at Jugu (Table 3). Similarly, highly significant difference ( $<<0.001)$ was observed among tested landraces for days to maturity at Ghanpokhara, Hanku and Khumaltar but non-significant at Jugu and Chhipra (Table 3). Long maturity period in Hanku and Chhipra was observed due to prolonged snowfall during the early vegetative stage of the crop. Plant height is a trait correlated with the straw yield which is one of the important selection traits for farmers raising livestock. Genotypes differed significantly for plant height at Ghanpokhara, Hanku and Khumaltar but the difference was not significant at Jugu and Chhipra (Table 4). The difference among the landraces for grain yield was highly significant $(\mathrm{p}<0.001)$ at Khumaltar and significant at Hanku but not significant at Ghanpokhara, Jugu and Chhipra (Table 4). The highest grain yield was obtained at Khumaltar whereas the lowest yield was at Jugu (Table 4).

Combined over locations data showed significant differences for heading $(\mathrm{P}<0.001)$, maturity $(\mathrm{P}<0.001)$ (Table 3), plant height $(\mathrm{P}<0.001)$ and grain yield $(\mathrm{P}<0.05)$ (Table 4). Landrace NGRC02327 was found the earliest for heading and maturity while combined over locations whereas NGRC04901 was the latest for heading and maturity. NGRC02306 was the highest yielding landrace followed by NGRC04902 and NGRC04894 (Table 4). Two out of eight tested landraces yielded above overall mean at Chhipra, two out of eight landraces produced higher grain yield than overall mean at Hanku and five out of eight tested landraces gave better yield than the overall mean at Khumaltar (Table 4), suggested that environment and management was favorable and high yielding compared to other sites.

Genotype $\times$ Environment $(\mathrm{G} \times \mathrm{E})$ interaction was highly significant for days to heading, days to maturity (Table 3) and plant height (Table 4) but only significant difference was observed for grain yield (Table 4). Individual regression coefficients (bi) ranged from 0.686 to 1.492 (Figure 2), whereas coefficient of determination $\left(R^{2}\right)$ ranged from $54 \%$ to $95 \%$ which suggested the model fit well and explained good proportion of variation. Overall mean yield was $1905 \mathrm{~kg} / \mathrm{ha}$ with minimum of $1355 \mathrm{~kg} / \mathrm{ha}$ and maximum of $2294 \mathrm{~kg} / \mathrm{ha}$ (Table 4).

Similarly, the regression coefficient (bi) and mean yield of individual landrace were plotted in the scatter plot in Figure 3 to select the stable and high yielding landrace. If regression coefficient is higher than 1, the genotype is adapted to high yielding environment and if the regression is lower than 1 , the genotype is adapted to low yielding environments. Genotypes with regression coefficient equal or close to 1 and yield above average were considered more stable and adapted to all environments (Bilbro and Ray, 1976). We found NGRC04894 was the most stable landrace $(b=1.033)$ adapted to all locations (Figure 3). Similarly, two landraces NGRC02306 and NGRC04902 were better adapted to 
high yielding environments like Khumaltar but they are very sensitive to environmental change, producing very low yield in less favorable environment and even better yields when subjected to the high yielding environments. In contrast, NGRC04901 was a stable genotype $(b=0.874)$ better adapted to low yielding environments (Figure 3).

Table 3. Mean days to heading and maturity of naked barley landraces across five locations

\begin{tabular}{|c|c|c|c|c|c|c|c|c|c|c|c|c|}
\hline \multirow[b]{2}{*}{ Accession } & \multicolumn{6}{|c|}{ Days to heading (day) } & \multicolumn{6}{|c|}{ Days to maturity (day) } \\
\hline & Chhipra & Hanku & $\begin{array}{c}\text { Ghanpo } \\
\text { khara }\end{array}$ & Jugu & Khumal & Mean \pm SE & Chhipra & Hanku & $\begin{array}{c}\text { Ghanpo } \\
\text { khara }\end{array}$ & Jugu & Khumal & Mean \pm SE \\
\hline NGRC04003 & 124 & 152 & 107 & 106 & 113 & $121 \pm 5.1$ & 172 & 195 & 156 & 149 & 146 & $164 \pm 5.6$ \\
\hline NGRC02327 & 114 & 143 & 91 & 91 & 92 & $107 \pm 6.2$ & 164 & 190 & 146 & 140 & 130 & $154 \pm 6.5$ \\
\hline NGRC04894 & 135 & 157 & 112 & 115 & 115 & $127 \pm 5.3$ & 171 & 199 & 167 & 160 & 145 & $169 \pm 5.7$ \\
\hline NGRC02306 & 135 & 159 & 103 & 107 & 105 & $122 \pm 7.1$ & 176 & 200 & 153 & 155 & 145 & $166 \pm 6.4$ \\
\hline NGRC04903 & 135 & 141 & 95 & 101 & 101 & $114 \pm 5.9$ & 169 & 190 & 154 & 152 & 137 & $160 \pm 6.0$ \\
\hline NGRC04902 & 137 & 144 & 109 & 105 & 105 & $120 \pm 5.2$ & 176 & 196 & 157 & 155 & 146 & $166 \pm 5.8$ \\
\hline NGRC04901 & 136 & 164 & 115 & 121 & 120 & $131 \pm 5.6$ & 175 & 201 & 167 & 162 & 151 & $172 \pm 5.5$ \\
\hline NGRC01137 & 139 & 162 & 109 & 105 & 107 & $125 \pm 6.8$ & 177 & 202 & 156 & 153 & 146 & $167 \pm 6.5$ \\
\hline Overall mean & 132 & 153 & 105 & 106 & 107 & 121 & 173 & 197 & 157 & 153 & 143 & 165 \\
\hline F-test: & & & & & & $* * *$ & & & & & & $* * *$ \\
\hline Location & - & - & - & - & - & & - & - & - & - & - & \\
\hline Genotypes & $* * *$ & $* * *$ & $* * *$ & ns & $* * *$ & $* * *$ & $\mathrm{~ns}$ & $* * *$ & $* * *$ & $\mathrm{~ns}$ & $* * *$ & $* * *$ \\
\hline Loc $\times$ Genotypes & - & - & - & - & - & $* * *$ & - & - & - & - & - & $* *$ \\
\hline $\mathrm{CV}(\%)$ & 6.47 & 5.78 & 8.10 & 10.9 & 8.15 & 16.1 & 8.50 & 4.63 & 4.43 & 9.70 & 4.97 & 13.1 \\
\hline $\operatorname{LSD}(\alpha=0.05)$ & 5.51 & 3.56 & 7.79 & - & 6.86 & 5.86 & - & 3.69 & 3.50 & - & 8.67 & 7.71 \\
\hline
\end{tabular}

Table 4. Mean plant height $(\mathrm{cm})$ and grain yield $(\mathrm{kg} / \mathrm{ha})$ of naked barley landraces across five locations

Plant height $(\mathrm{cm})$

\begin{tabular}{|c|c|c|c|c|c|c|c|c|c|c|c|c|}
\hline \multirow[b]{2}{*}{ Accession } & \multicolumn{6}{|c|}{ Plant height $(\mathrm{cm})$} & \multicolumn{6}{|c|}{ Grain yield (kg/ha) } \\
\hline & Chhipra & Hanku & $\begin{array}{c}\text { Ghanpo } \\
\text { khara }\end{array}$ & Jugu & Khumal & Mean \pm SE & Chhipra & Hanku & $\begin{array}{c}\text { Ghanpo } \\
\text { khara }\end{array}$ & Jugu & Khumal & Mean \pm SE \\
\hline NGRC04003 & 86 & 77 & 107 & 95 & 110 & $96 \pm 5.6$ & 2500 & 995 & 2205 & 720 & 3041 & $1935 \pm 337$ \\
\hline NGRC02327 & 83 & 79 & 114 & 96 & 100 & $95 \pm 5.3$ & 1167 & 1167 & 2456 & 1557 & 2622 & $1860 \pm 293$ \\
\hline NGRC04894 & 73 & 68 & 92 & 75 & 99 & $83 \pm 5.2$ & 2500 & 2017 & 2155 & 1345 & 2432 & $2116 \pm 279$ \\
\hline NGRC02306 & 83 & 68 & 101 & 61 & 91 & $82 \pm 5.3$ & 1834 & 2328 & 2493 & 1255 & 3062 & $2294 \pm 342$ \\
\hline NGRC04903 & 81 & 86 & 125 & 89 & 110 & $100 \pm 5.9$ & 1584 & 1461 & 1775 & 1414 & 2451 & $1773 \pm 290$ \\
\hline NGRC04902 & 86 & 82 & 113 & 78 & 119 & $98 \pm 5.9$ & 1750 & 1892 & 2153 & 1250 & 3807 & $2274 \pm 345$ \\
\hline NGRC04901 & 83 & 75 & 114 & 75 & 113 & $94 \pm 6.3$ & 1667 & 817 & 1195 & 639 & 2322 & $1355 \pm 217$ \\
\hline NGRC01137 & 82 & 75 & 111 & 73 & 110 & $92 \pm 6.2$ & 1000 & 1267 & 1540 & 802 & 3056 & $1630 \pm 304$ \\
\hline Overall mean & 82 & 76 & 110 & 80 & 107 & 93 & 1750 & 1493 & 1997 & 1123 & 2849 & 1905 \\
\hline F-test: & & & & & & $* * *$ & & & & & & $* * *$ \\
\hline Location & - & - & - & - & - & & - & - & - & - & - & \\
\hline Genotypes & ns & $* *$ & $* * *$ & ns & $* * *$ & $* *$ & ns & $*$ & ns & ns & $* * *$ & $*$ \\
\hline Loc $\times$ Genotypes & - & - & - & - & - & $* *$ & - & - & - & - & - & $*$ \\
\hline $\mathrm{CV}(\%)$ & 13.7 & 10.9 & 8.5 & 14.1 & 9.2 & 22.7 & 32.7 & 24.7 & 31.6 & 30.7 & 17.0 & 37.7 \\
\hline $\operatorname{LSD}(\alpha=0.05)$ & - & 8.8 & 8.7 & - & 8.2 & 14.9 & - & 1150 & - & - & 249.8 & 923 \\
\hline
\end{tabular}

Grain yield (kg/ha) 


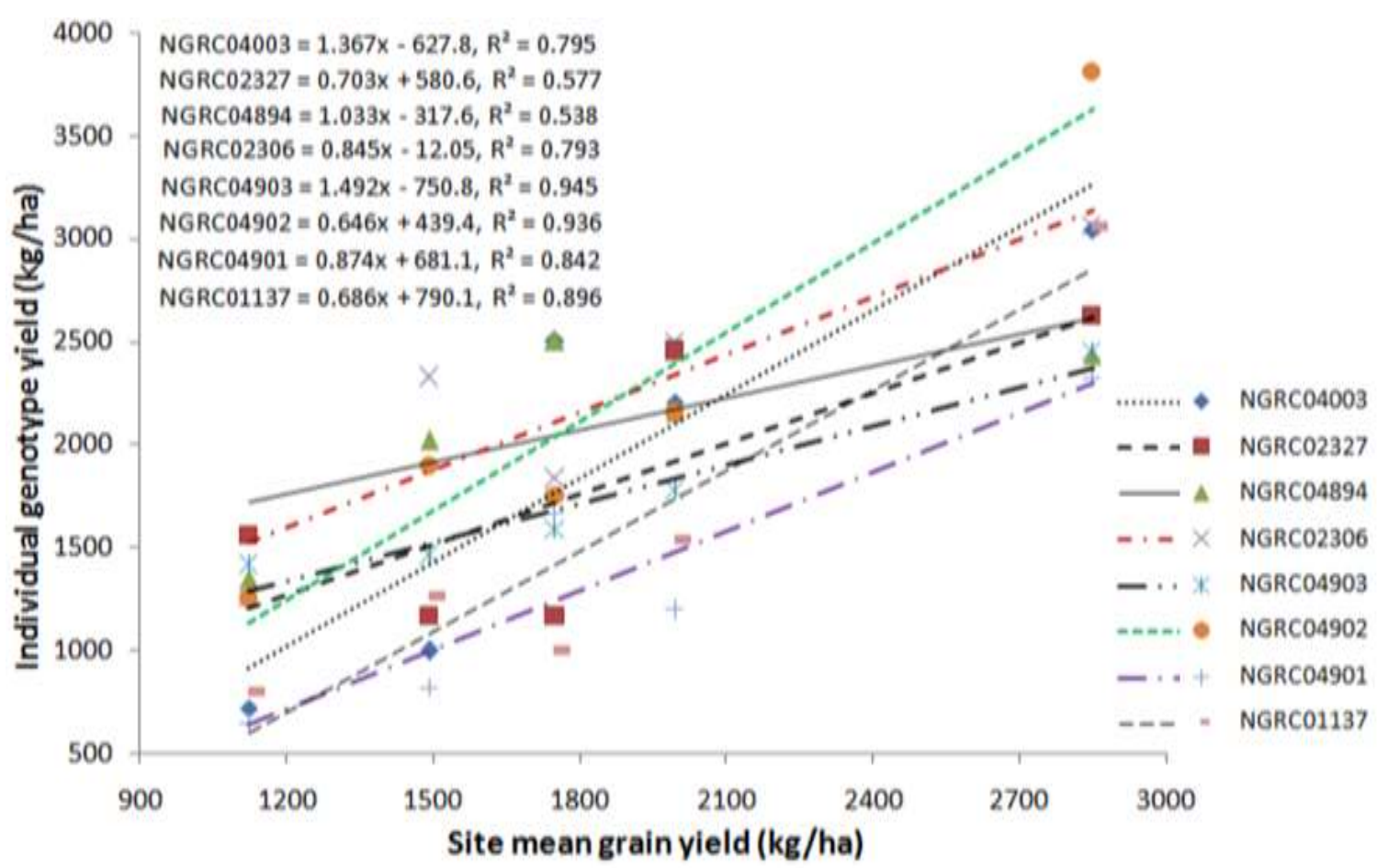

Figure 2. Regression lines showing the relationship between individual genotype yield and site mean yield of naked barley landraces

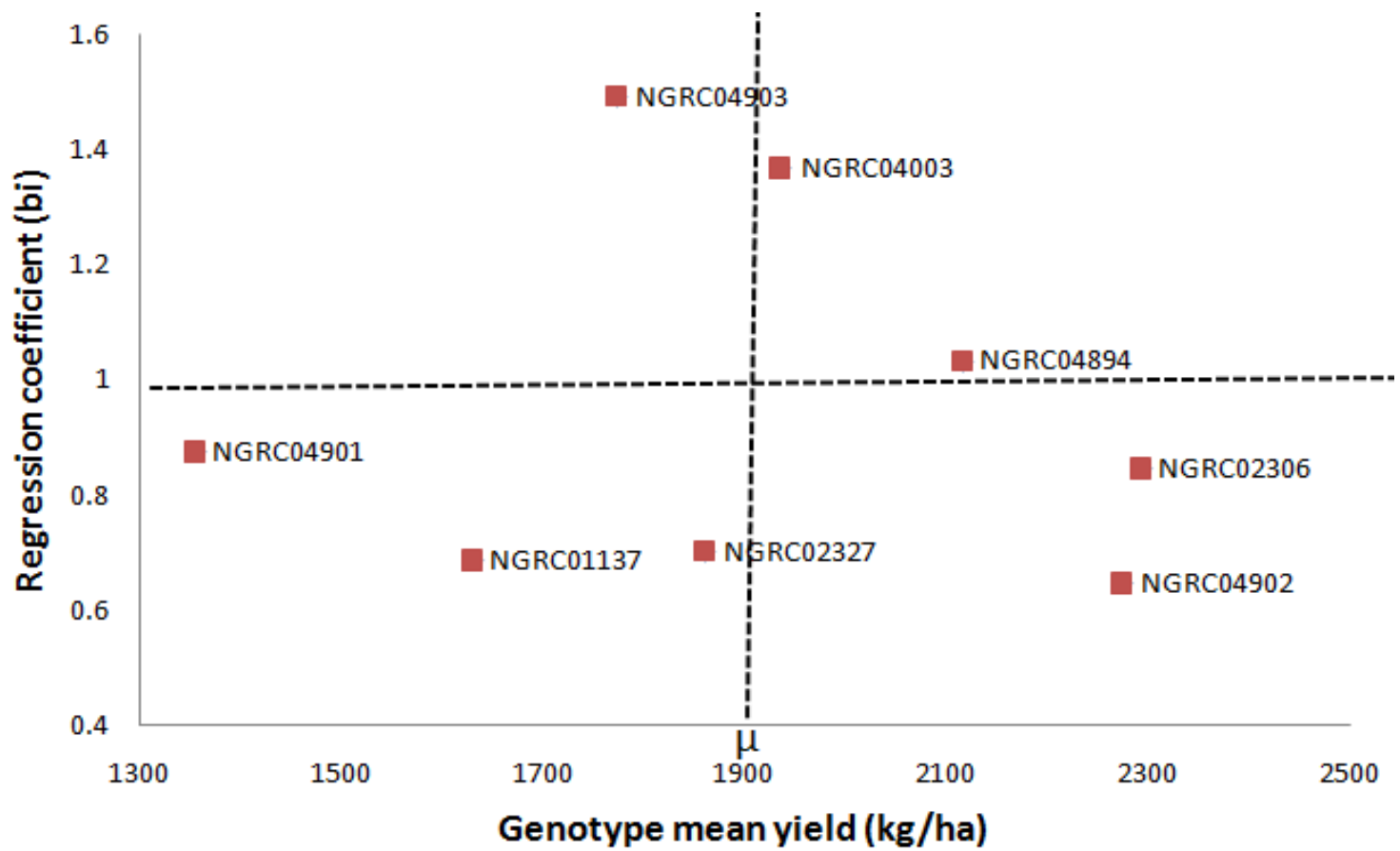

Figure 3. Relationship of genotype adaptation or regression coefficient (bi) with genotype mean yield of tested landraces $(\mu=$ population mean $)$. 


\section{DISCUSSION}

Landraces are populations that farmers select based on their functional traits, manage over time through a sequence of cropping seasons and become adapted to their local environments (Bajracharya et al 2012). Testing genotypes at more locations is considered important rather than testing in more years at the same location for stability studies (Saeed et al., 1984). Stability and adaptability studies are useful for recommending and releasing a genotype to cultivate in wide as well as specific environments (Witcombe 1975, Witcombe and Gilani 1979, Murphy and Witcombe 1982, Murphy et al 1982, Murphy and Witcombe 1986, Witcombe et al 2016, Pandey et al 2006). Those landraces could be further verified and multiplied in farmers' field for wider promotion. Evaluation of landraces across mountain environments showed significant differences in functional traits like grain yield, maturity and plant height. The results demonstrate high GxE interaction suggesting need of more localized varietal assessment. This study increased the opportunity to select genotypes adapted across locations and the high and low yielding environments. The application of this study will be used to distribute a set of Informal Research and Development (IRD) kits ie half $\mathrm{kg}$ seed per $\mathrm{HH}$ and 500 to 1000 kits (Joshi and Sthapit 1991, Sthapit et al 2017, Witcombe et al 2016) for deploying new diversity and provide farmers for participatory selection for their needs.

Diversity in landraces of traditional crops including naked barley has shrinking in mountainous region (Parajuli et al 2017, Palikhey et al 2017) as well as other parts of Nepal. In the crops like naked barley, farmers have few varietal selection options because there is only one variety officially released (NARC 2012, SQCC 2016). Genetic diversity of naked barley from mountain areas exists in the collection of National Genebank or in farmers' fields but they are not easily accessible to majority of farmers. Agro-morphological diversity among Nepalese naked barley landraces was assessed by Yadav et al (2018) and found these landraces superior in terms of agronomical traits and suggested to utilize in breeding program. Apart from screening naked barley landraces, crosses between covered and naked barley would release the genetic variability between these two forms. Farmers of mountain areas prefer varieties that have set of traits such as higher yield, earliness and high biomass. After onfarm trials in wider scale, these better performing varieties need to be released or registered so that the process would be mainstreamed and farmers' choices in this neglected crop would be increased.

\section{CONCLUSION}

Naked barley is an important winter crop in mountain region of Nepal but production area and genetic diversity is shrinking fast due to various challenges including very limited varietal options. Identification of stable superior naked barley genotypes is the most important task in variety development program. We found that NGRC04894 was the most stable genotype which can be grown in all environments. The genotypes namely NGRC02306 and NGRC04902 were suitable to be grown in Khumaltar. There was high genotype by environment $(\mathrm{GxE})$ interaction suggesting the need of more localized varietal assessment. In mountain region such as Jumla and Humla, farmers can prefer even the lower yielding but early maturing genotype i.e. NGRC02327 as it fits better in the rice based cropping system. These candidate genotypes need to be deployed to farmers' fields in wider areas followed by release or registration which would help to diversify the genetic portfolio of naked barley landraces in the mountain region.

\section{ACKNOWLEDGEMENTS}

This paper is the output of the GEF/UNEP supported project, "Integrating Traditional Crop Genetic Diversity into Technology: Using a Biodiversity Portfolio Approach to Buffer against Unpredictable Environmental Change in the Nepal Himalayas" implemented in Nepal. The project is coordinated by the Bioversity International in collaboration with Nepal Agricultural Research Council (NARC), Department of Agriculture (DoA) and Local Initiatives for Biodiversity Research and Development (LIBIRD). Authors would like to acknowledge for the field and technical support and encouragement of the following people: MR Bhatta and M Bhattarai from NAGRC, D Gauchan and late BR Sthapit from Bioversity International and Prof. John Witcombe from Bangor University, UK. 


\section{REFERENCES}

Baniya BK, DMS Dangol and KW Rilley. 1997. Characterization of Nepalese Barley germplasm. ICARDA, Syria. Rachis Barley and Wheat Newsletter 116: 16-19.

Bajracharya J, AHD Brown, BK Joshi, D Pandey, BK Baniya, BR Sthapit and DI Jarvis. 2012. Traditional seed management and genetic diversity in barley varieties in high-hill agro-ecosystems of Nepal. Genet Resour Crop Evol 59:389-398. https://doi.org/10.1007/s10722-011-9689-2.

Bhatty RS. 1999. The potential of hullless barley. Cereal Chem 76: 589-599. http://dx.doi.org/10.1094/CCHEM.1999.76.5.589.

Bilbro JD and LL Ray, 1976. Environmental stability and adaptation of several cotton cultivars. Crop Sci. 16: 821-824. http://dx.doi.org/10.2135/cropsci1976.0011183X0016000 60021x.

Finley KW and GN Wilkinson. 1963. The analysis of adaptation in plant breeding program. Aust. J. Agric. Res. 14: 742-754. http://dx.doi.org/10.1071/AR9630742.

IPGRI. 1994. Descriptors for Barley (Hordeum vulgare L.). International Plant Genetic Resources Institute, Rome, Italy. https://www.bioversityinternational.org/e-library/publications/detail/descriptors-for-barleyhordeum-vulgare-1/

Joshi BK, MR Bhatta, KH Ghimire, M Khanal, SB Gurung, R Dhakal and B Sthapit. 2017. Released and promising crop varieties of mountain agriculture in Nepal (1959-2016). LIBIRD, Pokhara; NARC, Kathmandu and Bioversity International, Pokhara, Nepal. http://himalayancrops.org/project/ released-andpromising-crop-varieties-for-mountain-agriculture-in-nepal-1959-2016/

Manjunatha T, IS Bisht and KV Bhat. 2011. Genetic structure of hullless barley (Hordeum vulgare) landrace populations from north-western Indian Himalayas. Indian Journal of Biotechnology. Vol 10, January 2011, pp.25-32.

MOAD. 2015. Statistical Information on Nepalese Agriculture, 2014/015. Government of Nepal, Ministry of Agricultural Development, Agribusiness Promotion and Statistics Division, Kathmandu, Nepal.

Murphy PJ and JR Witcombe. 1986. Covered and naked barleys from the Himalaya. Theor Appl Genet 71: 730735. https://doi.org/10.1007/BF00263271.

NARC. 2012. Released and Registered Crop Varieties in Nepal, 1960-2012. Communication, Publication and Documentation Division (CPDD), Nepal Agricultural Research Council (NARC), Khumaltar, Lalitpur.

Palikhey E, SR Sthapit, D Gauchan and BR Sthapit. 2017. Baseline Survey Report, Haku, Jumla, Pokhara: LIBIRD, NARC, DOA and Bioversity International. http://himalayancrops.org/project/baseline-reporthanku-jumla/

Pandey MP, C Wagner, W Friedt and F Ordon. 2006. Genetic relatedness and population differentiation of Himalayan hulless barley (Hordeum vulgare L.) landraces inferred with SSRs. Theor Appl Genet (2006) 113: 715-729. https://doi.org/10.1007/s00122-006-0340-0.

Parajuli A, A Subedi, SR Sthapit, D Gauchan, A Adhikari, and BR Sthapit. 2017. Baseline Survey Report, Chhipra, Humla, Pokhara: LI-BIRD, NARC, DOA and Bioversity International. http://himalayancrops.org/project/baseline-survey-report-chhipra-humla/

Sthapit BR, D Gauchan, S Sthapit, KH Ghimire, BK Joshi, DI Jarvis and J Herrle. 2017. A field guide to participatory methods for sourcing new crop diversity. NARC, LIBIRD and Bioversity InternationalNepal. http://himalayancrops.org/project/a-field-guide-to-participatory-methods-for-sourcing-new-cropdiversity/

Rajbhandari BP and GD Bhatta. 2008. Food Crops: Agro-ecology and Modern Agro-Techniques. Kathmandu, Nepal. Himalayan College of Agricultural Sciences and Technology. pp.72-75.

Saeed M, CA Francis and JR Rajowaski. 1984. Maturity effects on genotype x environment interaction in grain sorghum. Agron. J. 76: 55-58. https://doi.org/10.2134/agronj1984.00021962007600010015x.

Saud NB. 2010. Crops of Nepal and their sustainable farming (in Nepali: Nepalka Balinali ra Tinko Digo Kheti). Sajha Prakashan, Lalitpur, Nepal. pp.198.

Singh C. 1983. Modern techniques of raising field crops. Oxford and IBH Publishing Co. Pvt. Ltd., India. pp.126. https://www.cabdirect.org/cabdirect/abstract/20043168252.

SQCC. 2016. Notified seed varieties from National Seed Board 2072 (BS). Seed Quality Control Centre, Ministry of Agriculture Development, Government of Nepal, Hariharbhawan, Lalitpur, Nepal. http://sqcc.gov.np/en/publications/

Tonoka T, E Aoki, T Yoshioka and S Taketa. 2009. A novel mutant gene for (1-3,1-4)- $\beta$-D-glucanless grain on barley (Hordeum vulgare L.) chromosome 7H. Breeding Science 59: 47-54. https://doi.org/10.1270/jsbbs.59.47.

Witcombe JR and MM Gilani. 1979. Variation in cereals from the Himalayas and the optimum strategy for sampling plant germplasm. Journal of Applied Ecology. Vol 16: pp 633-640. DOI: 10.2307/2402537. https://www.jstor.org/stable/2402537. 
Witcombe JR. 1975. Wheat and barley from two Himalayan regions. Euphytica 24: 431-434.

https://doi.org/10.1007/BF00028210.

Yadav RK, S Gautam, E Palikhey, BK Joshi, KH Ghimire, R Gurung, AR Adhikari, N Pudasaini and R Dhakal. 2018. Agro-morphological diversity of Nepalese naked barley landraces. Agriculture and Food Security (2018) 7:86. https://doi.org/10.1186/s40066-018-0238-5.

|1-------||-------|| 